\title{
The Impacts of Financial Freedom on International Real Estate Securities
}

\author{
Mei-Se Chien ${ }^{1}$, Chih-Yang Cheng, ${ }^{2, *}$, Yi-Chung Hsu ${ }^{3}$ \\ ${ }^{1}$ Department of Finance and Information, National Kaohsiung University of Science and Technology, Taiwan, China \\ ${ }^{2}$ Department of Finance, National Sun Yat-Sen University, Taiwan, China \\ ${ }^{3}$ Department of Public Finance and Taxation, National Taichung University of Science and Technology, Taiwan, China
}

Received September 19, 2019; Revised November 13, 2019; Accepted November 23, 2019

Copyright $\bigcirc 2019$ by authors, all rights reserved. Authors agree that this article remains permanently open access under the terms of the Creative Commons Attribution License 4.0 International License

\begin{abstract}
The aim of the paper is to study how trade freedom and financial freedom affect the excess return of real estate security, and we apply annual data for 1,108 publicly traded real estate companies of 24 countries from 2006 to 2013 to examine it. The main findings are as follows : First, for whole sample, the coefficients of the index of trade freedom, the index of financial freedom, are significantly negative, which means that higher freedom of trade and financial will increase efficiency of real estate market but the excess return of real estate will decrease. Second, comparing the effect of the indexes to affect excess return of real estate securities in three different regions, the indexes of financial freedom and Trade freedom are vital factors, but all of four indexes of freedom are important in Europe and other area. Third, the coefficients of indexes of monetary freedom and indexes of trade freedom are negative in both of high and non-high income groups. Finally, for the group of non-high income level, the coefficient of index of investment freedom is negative and the coefficient of index of financial freedom is positive, which are different with the results of the whole sample.
\end{abstract}

Keywords Real Estate, Trade Freedom, Financial Freedom, Generalized Method of Moment

\section{Introduction}

Real estate has traditionally been regarded as a local phenomenon. In the past few decades, globalization has progressively brought about the internationalization of services sectors as much as of manufacturing, which caused many sub-sectors of the real estate industry have been enthusiastic participants in the global surge (Bardhan and Kroll [3]). In the past two decades, globalization has multiplied and the importance of trade liberalization, such as Free Trade Agreement (FTA), and financial liberalization is increasing dramatically. Trade liberalization promotes the economic integration across countries, which will reduce the trade costs and motivate the growth of trade demand. Hence, trade liberalization of a country usually will bring about higher economic profit. As to financial liberalization, which can cause that foreign investors are able to add foreign real estate physical assets or foreign real-estate-related financial securities to their portfolio, as well as also facilitate the participation by domestic real estate firms in global opportunities. However, trade liberalization and financial liberalization will promote the global economic integration, which will also bring about closer linkage of international real estate securities. In the trend of trade and financial liberalization, how will the international real property securities be affected by these factors?

Reviewing the past relative literature, the issue of international diversification of real estate portfolios has received more discussions, such as $[9,11,29,31,32,33$, 36], among others. Some studies analysis the relationship between economic openness, especially current account or capital inflows, and the real estate sector. $[1,18,19,28]$ There is little existing literature which includes openness or capital flows to compare real estate security returns across countries, but Bardhan et al. [4] is an exceptional literature, which shows that a country's openness will negatively affect real estate security excess returns. However, there is no literature to study the relationship between economic freedom and real estate security returns. For fill the gap, the paper establish a model to estimate the impacts of the indices of financial freedom and trade freedom on real estate firms securities returns.

This paper contributes to the relevant literature of real estate security returns across countries as follows: First, although some empirical studies have showed that a 
positive relationship exists between economic freedom and GDP $[7,10,23,24,38]$, such a linage has yet to be discussed between economic freedom and real estate security returns. Considering financial liberalization and trade liberalization could change return of the real estate securities, this paper provides new evidence that sheds light on the topic by adding four indices of economic freedom into multifactor model of Bardhan et al. [4] to estimate the impact of economic freedom index on real property securities. Second, the paper applies a dataset sufficiently large to allow robust conclusions to be drawn; specifically, the sample used in this study consists of annual data for 1,108 publicly traded real estate companies from 24 countries over the period 2006 - 2013. Comparing with the dataset of Bardhan et al. [4], annual data for 946 firms of 16 countries form 1995 to 2002 , the paper uses a wide and updated range of data, including more developing countries' data and more up-to-date data. Third, the methodology of Bardhan et al. [4] is a static panel model, pooled regression, which cannot allow us to analyze the possible dynamism existing in multifactor model of return of real estate securities. Hence, the paper uses dynamic panel estimators, dynamic generalized method of moments (GMM), rather than static panel models to avoid the fault of pooled regression. The general estimates are considered for the sample covering shorter periods and more countries, and the explanatory variables of estimating model are not strictly exogenous, fixed effects, the heteroscedasticity, as well as autocorrelation within countries.

The remainder of the paper is as follows. Section 2 provides a summary of the literature. Section 3 describes the methodology. Section 4 presents the empirical results, and Section 5 provides some conclusions.

\section{Literature}

In past literature of real estate markets, some studies have investigated about international determinants of real estate returns across different country. Some papers put the light on international real estate diversification and discuss mean-variance portfolio performance, such as [11, 22]. Eichholtz [11] analysis the covariance structure of international real estate returns by applying monthly data from 1973 to 1993, and the result of Eichholtz [11] displays that the covariance of international real estate returns is unstable. Goetzmann and Wachter [22], employing mean-variance analysis, confirm that three clusters of office markets that tend to move together by using the sample of office markets across countries and classify three groups to research by achieving the mean-variance analysis.

Conover et al. [8] demonstrate that not only foreign shares but also foreign real property security offer diversification gains. Hoesli et al. [27] employ both hedged and unhedged returns and indicate that portfolio diversification benefits will be improved if real estate assets are included in a mixed-asset portfolio. Some other studies have documented the benefits of including real estate in mixed-asset portfolios [34, 35, 40]. Recently, the issue of international diversification of real estate portfolios has received more discussions. Worzala and Sirmans [41] have remarkably reviewed international real estate stock literature, which put a light on the diversification benefits in a mixed-asset portfolio framework or a real estate-only portfolio framework. Other literature contains $[9,13,29,31,32,33,36]$.

Some papers study the impacts of international world-wide regional and country-specific factors on international real estate security returns. Eichholtz et al. [14] examine whether the continental factors will influence on return of real estate, and the results confirm the existence of "continental" differences of real estate returns in European, North American and Asia-Pacific. For a sample of 21 countries, Hamelink and Hoesli [26] discuss the effects of various factors on real estate security returns across different countries, and their result shows that there are some significant factors, such as country, scale and value/growth, to influence return. Eichholtz and Huisman [12] investigate the factors to determine the cross-sectional variation of excess returns on international property firms, and they find that interest rates, firm size and country-specific variables are significant factors. Being based on an international CAPM model, Ling and Naranjo [30] find little proof of abnormal and risk-adjusted returns for real estate firms at the country level, but there are a strong worldwide factor and an orthogonal country-specific factor to drive the return of international real estate. Similarly, in this study of Bond et al. [6] it employ the data of country-level commercial real estate indexes by using the CAPM and controlling for Fama and French [16] factors.to examine the risk and return of publicly traded real estate, their finding presented the country-specific risk and the Fama and French [17] factors are significant determinants of real estate returns. We are aware of other papers which support the same evidence, such as $[20,21,37,39]$.

Some recent studies analyze the relationship between economic openness, especially current account or capital inflows, and the real estate sector. Aizenman and Jinjarak [1] regresses changes in real estate prices on the ratio of current account to GDP by using cross-country data from 43 countries, their results display that the current account is negatively correlated with real estate prices. While other relative empirical works also find that a positive and significant relationship between capital inflows and booms in real estate prices such as $[1,18,19,28]$. In particularly, taking international economic openness into the model, Bardhan et al. [5] indicate that openness of national economies has a positive impact on urban residential rents among 55 cities around the world. However, there is little existing literature comparing real estate security returns across countries to include international economics variables, such as measures of openness or capital flows. 
Empirical research by Bardhan et al. [4] is an exceptional literature, which examine the impact of a country's economic openness on returns of real estate firms, using a set of multifactor models for annual data for 946 firms from 16 countries. The results of Bardhan et al. [4] show that a country's openness will negatively affect real estate security excess returns.

Recently, some empirical studies have showed that economic freedom leads economic growth (Heckelman [25]) and that a positive relationship exists between economic freedom and GDP [7, 10, 23, 24, 38]. However, such an association has yet to be discussed between economic freedom and real estate security returns. Hence, being based on the model of Bardhan et al. [4], the paper will examine how economic freedom affect a country's economic openness on returns of publicly traded real estate firms, controlling for the effects of global capital markets, domestic economic and firm-specific variables.

\section{Methodology}

The paper applies the Generalized-Method-of-Moments (GMM) method of Arellano and Bond [2] for dynamic panel data, which can eliminate weak instrumental variable and enhance the effectiveness of the limited sample. Our panel consists of data for 1,108 publicly traded real estate firms of 24 countries over the period 2006-2013. For analysis how trade freedom and financial freedom affect the excess return of real estate security, the paper adds some indices of economic freedom into multifactor model of Bardhan et al. [4] to examine the effects. The corrected model takes the form:

$$
\begin{array}{r}
R\left(R_{i, j, t}-R_{j, t}\right)=\beta_{1} R\left(R_{i, j, t-1}-R_{j, t-1}\right)+\beta_{2} M K T_{j, t}+ \\
\beta_{3} \operatorname{SIZE}_{i, j, t}+\beta_{4} P T B V_{i, j, t}+\beta_{5} L N T U R_{i, j, t}+\beta_{6} G D P_{j, t}+\beta_{7} S P R E A D_{j, t} \\
\beta_{8} O P E N N E S S_{j, t}+\beta_{9} F D I / G D P_{j, t}+\beta_{10} T F_{j, t}+\beta_{11} M F_{j, t}+ \\
\beta_{12} I F_{j, t}+\beta_{13} F F_{j, t}+\varepsilon_{i, j, t}
\end{array}
$$

Where $R_{i, j, t}$ is the estimated exposure of firm i's real estate return for the country $\mathrm{j}$ in time period $\mathrm{t}$, and $R_{j, t}$ is the country $\mathrm{j}$ 's risk-free rate in time period $\mathrm{t}$, hence, the dependent variable, $R_{i, j, t}-R_{j, t}$, means the firm i's real estate excess annual return over country $j$ 's risk-free rate in period $t$.

As to the independent variables, $M K T$ represents the realized excess return for market portfolio over risk-free rate. SIZE, $P T B V$, and LNTUR are firm's market capitalization and annual total trading volume, respectively, and both are measured in U.S. dollars. PTBV is the company market capitalization divided by reported book value. Moreover, there are two independent macroeconomic variables, that is, $G D P$ is change in gross domestic product and SPREAD is calculated by using "10-year bond rate" be reduced by "3-month treasure rate". Furthermore, the model includes some variables to measure globalization and liberalization, being shown as the followings: OPENNESS is exports plus imports as a percentage of GDP, as a measure the degree of openness for the country; FDI/GDP the ratio of Foreign Direct Investment (FDI) to the GDP, as a measure the degree of globalization; $T F$ represents the index of trade freedom; $M F_{i, t}$ represents the index of monetary freedom; $F F$ represents the index of investment freedom; $F F$ represents the index of financial freedom. Finally, cis the error term. The subscript $i$ represents firm $i, j$ means country $i$, and $t$ is period $\mathrm{t}$.

\section{Data and Empirical Results}

This research examines the dynamic linkages of excess return of real estate security, macroeconomic variables, trade freedom, and financial freedom by applying panel data. This section will estimate the multifactor model with some indices of different economic freedom, as equation (1), by using the method about Generalized Method of Moment (GMM) to investigate the impacts of trade freedom and financial freedom on the excess return of real estate securities.

\subsection{Data}

This empirical analysis covers annual data for 1,108 publicly traded real estate companies from 24 countries among 2006 to 2013. The numbers of firms in our sample are more than the numbers of firms in previous research, for example, the sample of Eichholtz et al. [14] covered 250 biggest real property companies, and the sample of Bardhan et al. [4] included 946 real estate firms. The study utilizes 1,108 real estate firms, and Figure 1 show the numbers of firms in our sample by country. 


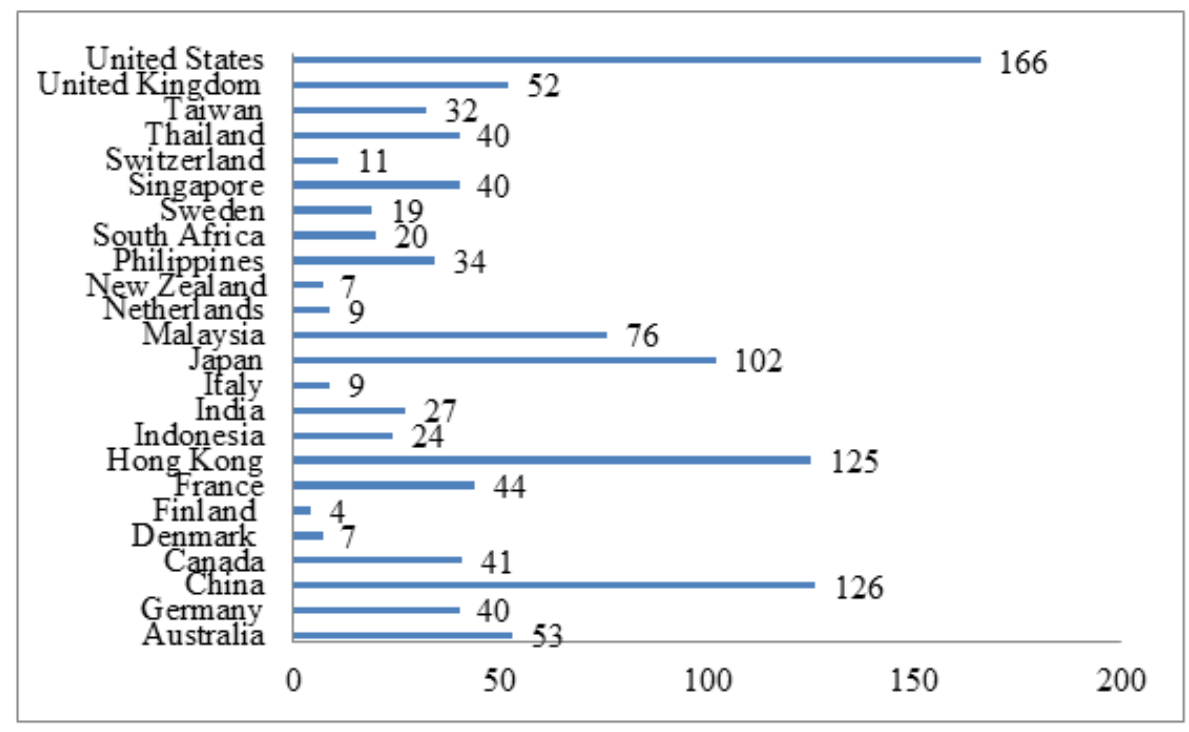

Figure 1. Sample number of firms by country

The equation (1), controlling for the effects of global capital markets, domestic macroeconomic conditions and firm-specific variables, will be estimated by using generalized method of moment (GMM). Except for the dependent variable being the realized return of publicly traded real estate equity for company, the independent variables of equation (1) include the excess annual returns of market, size of company, market value to book value , interest spread, GDP, trading volume, openness 1, index of global, and several indices of economic freedom. It is worth noting that some literature, for example Fard et al. [15], selected FDI/GDP as a proxy variable to measure the degree of globalization, hence, this paper also includes FDI/GDP to be one of indexes of globalization. The data of all variables are collected as the followings: The data of GDP and openness are obtained from IMF website, the data of several economic freedom indexes obtain from Heritage Foundation website, and the other data of variables are from Datastream Database.

Being different from the model of Bardhan et al. [4], the model of the research includes several indices of economic freedom. The first is the index of trade freedom which is a measure of the absence of tariff and non-tariff barriers that affect imports and exports of goods and services. The second is the index is monetary freedom which is a measure of price stability with an assessment of price controls. Both of inflation and price controls distort market activity. The third is the index of investment freedom which is a measure whether constraints on the flow of investment capital. The fourth is the index of financial freedom which is a measure of banking efficiency as well as a measure of independence from government control and interference in the financial sector. Table 1 presents detailed definitions and proxies of all variables as well as the sources of the data.

Table 1. The data of variables

\begin{tabular}{|c|c|c|}
\hline Variables & Proxy & Source \\
\hline $\begin{array}{l}\text { excess return of publicly traded } \\
\text { real estate equity }\end{array}$ & $\mathrm{R}$ & Datastream $^{\mathrm{a}}$ \\
\hline excess return of market & MKT & Datastream $^{a}$ \\
\hline Firm's market capitalization & SIZE & Datastream \\
\hline Market-to-book ratio & PTBV & Datastream \\
\hline $\begin{array}{l}\text { Total value of firm's trading } \\
\text { volume (turnover) }\end{array}$ & LNTUR & Datastream \\
\hline Gross domestic product & GDP & IMF \\
\hline Rate spread & SPREAD & Datastream $^{\mathrm{b}}$ \\
\hline openness & OPENNESS & $\mathrm{IMF}^{\mathrm{c}}$ \\
\hline Global index & FDI/GDP & $\begin{array}{c}\text { The world } \\
\text { Bank }\end{array}$ \\
\hline Index of Trade Freedom & $\mathrm{TF}$ & $\begin{array}{l}\text { Heritage } \\
\text { Foundation }\end{array}$ \\
\hline Index of Monetary Freedom & MF & $\begin{array}{l}\text { Heritage } \\
\text { Foundation }\end{array}$ \\
\hline Index of Investment Freedom & IF & $\begin{array}{c}\text { Heritage } \\
\text { Foundation }\end{array}$ \\
\hline Index of Financial Freedom & $\mathrm{FF}$ & $\begin{array}{c}\text { Heritage } \\
\text { Foundation }\end{array}$ \\
\hline
\end{tabular}

a. $\quad \mathbf{R}=\mathbf{R}_{\mathbf{i t}}-\mathbf{R}_{\mathbf{f t}}, \mathbf{R}_{\mathbf{i t}}$ is realized return of publicly traded real estate equity, and $\mathbf{R}_{\mathbf{f t}}$ is risk-free rate of country, and both are collected from Datastream. Besides, $\mathrm{MKT}=\mathbf{R}_{\text {st }}-\mathbf{R}_{\mathbf{f t}}, \mathbf{R}_{\mathbf{s t}}$ is realized returns of the stock index for country.

b. Rate spread is calculated by using " 10 -year bond rate" be reduced by " 3 -month treasure rate", and both rates are collected from Datastream.

c. Openness $=($ imports + exports $) / G D P$, both imports, exports and GDP are collected from IMF. 
Table 2. The countries in different subsamples

\begin{tabular}{|c|c|c|c|c|c|}
\hline & \multicolumn{2}{|c|}{ Asia } & \multicolumn{2}{|c|}{ Europe } & Other \\
\hline \multirow{5}{*}{ Area } & Hong Kong & India & United Kingdom & Netherlands & Canada \\
\hline & Singapore & Indonesia & France & Demark & United States \\
\hline & Japan & Philippines & Germany & Switzerland & New Zealand \\
\hline & Taiwan & Thailand & Italy & Finland & Australia \\
\hline & China & Malaysia & Sweden & & South Africa \\
\hline \multirow{7}{*}{ Income level } & \multicolumn{3}{|c|}{ High income } & \multicolumn{2}{|c|}{ non-high income } \\
\hline & United Kingdom & Netherlands & Singapore & China & Thailand \\
\hline & France & Demark & Japan & India & Malaysia \\
\hline & Germany & Switzerland & Taiwan & Indonesia & South Africa \\
\hline & Italy & Finland & Canada & Philippines & \\
\hline & Sweden & Hong Kong & United States & & \\
\hline & New Zealand & Australia & & & \\
\hline
\end{tabular}

Additionally, in order to compare the results of different samples by different areas and by income levels, the research also will execute GMM estimations of three area-subsamples and two income-subsamples. Three area-subsamples include Asia, Europe and other area. According to income classifications of the World Bank in 2013, the paper divided the 24 countries into high income group (GNI per capita $>$ US\$12,736) and non-high income group (GNI per capita $<$ US\$12,736). Table 2 presents the classification results.

\subsection{The GMM Estimation of the Whole Sample}

Table 3 displays sets of GMM estimated results to Equation (1) for the whole sample of 24 countries. In Table 3, models (1) and (2) are the model of single-factor CAPM, the former does not include OPENNESS but the latter does. Being based on models (1) and (2), models (3), (4) and (5) include different factors of company and macroeconomics. In model (3), according to the suggestion of Bardhan et al. [4], except for excess return of market (MKT), there are three variables of company, that is, firm's size (SIZE), market-to-book ratio (MKT), and trading volume (LNTUR), as well as two macroeconomic variables, including GDP growth and interest rate spread. Comparing with model (3), model (4) adds one more variable, OPENNESS, to examine the effect of globalization on excess return of property firm. Being different from model (4), model (5) includes a different variable, globalization indicators (FDI/GDP), to replace OPENNESS for investigating the effect of globalization on excess return of property firm, while model (6) considers both openness and FDI/GDP. Another group is models with freedom indicators, including models (7) and (8). The model (7) is added three indices of economic freedom, IF, MF, and FF, into model (6), and model (8) contains all of variables.

The result of model (1), in column 1 of Table 3, show that the coefficient of MKT, excess return of market, is significantly positive, which means that increasing excess return of market will raise the realized return of real estate company. Then, model (2) is added the variable OPENNESS, (imports + exports)/GDP, into model (1), to investigate the effect of openness. The estimated coefficient of MKT, in model (2), is also positive, same as the result of model (1). Comparing the results of other models in Table 3, several features can present as the followings.

First, according to Table 3, we can find the coefficients of the variable $\mathrm{R}(-1)$, the lag of excess return for real estate, are positive in most of models, which means that there are continuous impacts on excess return of real estate. On the other hand, the results of most of models show the coefficient of the MKT is significantly positive, which means real estate firm returns are positive to excess return of market. Second, the log of firm size is negative, which supports the argument of a small firm effect of Fama and French [16]. In other words, real estate firm returns are negative to firm size, which means that investors may be able to get abnormal profits by investing in smaller real estate firms. Third, the coefficients of the market-to-book ratio and trading volume, for most of models, is insignificant at 5\% level, which is same as the finding of Bardhan et al. [4]. Fourth, as to the proxies for the local demand and the local supply factors, for most of models, the coefficient of GDP growth is positive and the coefficient of interest rate spread is negative, which is same as theoretical expectation. 
Table 3. The results of GMM for all countries

\begin{tabular}{|c|c|c|c|c|c|c|c|c|}
\hline Variables/Model & 1 & 2 & 3 & 4 & 5 & 6 & 7 & 8 \\
\hline \multirow{2}{*}{$\mathrm{R}(-1)$} & $0.235^{* *}$ & $0.163 * * *$ & 0.012 & $0.108^{* * *}$ & $0.060^{*}$ & $0.129 * * *$ & $0.144 * *$ & $0.146^{* *}$ \\
\hline & $(0.041)$ & $(0.000)$ & $(0.990)$ & $(0.001)$ & $(0.062)$ & $(0.002)$ & $(0.030)$ & $(0.037)$ \\
\hline \multirow{2}{*}{ MKT } & $9.862 * * *$ & 5.543 & 10.574 & 18.418 & 16.212 & 2.638 & $39.964 * *$ & $20.920^{* *}$ \\
\hline & $(0.000)$ & $(0.504)$ & $(0.473)$ & $(0.122)$ & $(0.231)$ & $(0.866)$ & $(0.021)$ & $(0.030)$ \\
\hline SIZE & & & $\begin{array}{l}-12.095 \\
(0.729) \\
\end{array}$ & $\begin{array}{l}-26.653 \\
(0.399) \\
\end{array}$ & $\begin{array}{c}-12.420^{* *} \\
(0.010) \\
\end{array}$ & $\begin{array}{l}-13.354 \\
(0.646) \\
\end{array}$ & $\begin{array}{c}-14.671^{* *} \\
(0.031)\end{array}$ & $\begin{array}{c}-11.320^{*} \\
(0.081) \\
\end{array}$ \\
\hline \multirow{2}{*}{ PTBV } & & & -0.122 & -0.055 & $-0.361 * * *$ & 0.016 & -0.242 & -0.273 \\
\hline & & & $(0.920)$ & $(0.534)$ & $(0.000)$ & $(0.872)$ & $(0.319)$ & $(0.322)$ \\
\hline \multirow{2}{*}{ LNTUR } & & & $-4.701 * * *$ & $-6.516^{* * *}$ & $-6.278 * *$ & $-8.685 * * *$ & -4.585 & $-4.363 * * *$ \\
\hline & & & $(0.008)$ & $(0.008)$ & $(0.025)$ & $(0.000)$ & $(0.205)$ & $(0.003)$ \\
\hline \multirow{2}{*}{ GDP } & & & 19.854 & 19.711 & 35.616 & 39.651 & 15.523 & $15.420^{*}$ \\
\hline & & & $(0.348)$ & $(0.372)$ & $(0.154)$ & $(0.157)$ & $(0.432)$ & $(0.073)$ \\
\hline \multirow{2}{*}{ SPREAD } & & & $-26.064 *$ & -15.238 & -10.541 & -17.443 & $-16.774 * * *$ & $-15.970 * *$ \\
\hline & & & $(0.078)$ & $(0.149)$ & $(0.332)$ & $(0.234)$ & $(0.004)$ & $(0.041)$ \\
\hline OPENNESS & & $\begin{array}{l}-1.023 \\
(0.348) \\
\end{array}$ & & $\begin{array}{c}-0.542 \\
(0.847) \\
\end{array}$ & & $\begin{array}{l}-1.347 \\
(0.496) \\
\end{array}$ & $\begin{array}{c}-1.280^{* *} \\
(0.025)\end{array}$ & $\begin{array}{l}-1.422 \\
(0.344)\end{array}$ \\
\hline FDI/GDP & & & & & $\begin{array}{c}16.063^{* * * *} \\
(0.005)\end{array}$ & $\begin{array}{c}28.528^{* * * *} \\
(0.000)\end{array}$ & $\begin{array}{l}28.805^{*} \\
(0.060)\end{array}$ & $\begin{array}{c}29.824^{*} \\
(0.091)\end{array}$ \\
\hline IF & & & & & & & $\begin{array}{l}6.268^{*} \\
(0.065)\end{array}$ & $\begin{array}{c}6.661^{* *} \\
(0.014) \\
\end{array}$ \\
\hline MF & & & & & & & $\begin{array}{c}-3.102 * * \\
(0.036)\end{array}$ & $\begin{array}{c}-3.451^{* *} \\
(0.032) \\
\end{array}$ \\
\hline $\mathrm{FF}$ & & & & & & & $\begin{array}{l}-3.940 \\
(0.451) \\
\end{array}$ & $\begin{array}{c}-4.112 * * \\
(0.041) \\
\end{array}$ \\
\hline $\mathrm{TF}$ & & & & & & & & $\begin{array}{c}-8.459 * * * \\
(0.004)\end{array}$ \\
\hline P-Value & 0.672 & 0.365 & 0.659 & 0.987 & 0.955 & 0.873 & 0.842 & 0.689 \\
\hline
\end{tabular}

Note: P-Values are presented in parentheses. *Significance at the $10 \%$ level, $* *$ Significance at the $5 \%$ level, $* * *$ Significance at the $1 \%$ level. The Sargan test: The null hypothesis is defined as the instruments used that are not correlated with the residuals.

Moreover, there are some furthermore discussions of effects of openness and economic freedom on the excess return of real estate securities as the followings. First, the coefficient of OPENNESS for most of models is negative, same as the result of Bardhan et al. [4], which displays that real estate firm excess returns decrease in the more open economies. Second, comparing the results of models (4) and (5), the coefficient of OPENNESS is significantly negative, but the coefficient of FDI/GDP is significantly positive, which shows that increasing international trade will reduce real estate firm excess returns while increasing Foreign Direct Investment (FDI) will increase real estate firm excess returns.

Third, according to the results of models (7), including three indices of economic freedom, the coefficient of IF is positive, but the coefficients of MF and FF are negative, which implies increasing investment freedom will cause higher excess return of real estate securities, conversely, higher monetary freedom and financial freedom will decrease excess return of real estate securities but the coefficient of FF is insignificant. What caused the results? If the government deregulates some constraints of investment capital, investors can more freely allocate the portfolios of their investment, which could cause that the investors have higher possibilities to get higher returns of financial commodities, such as real estate securities. Additionally, lower monetary freedom means higher inflation which will cause higher price of real estate for investor to hedge the risks of higher inflation, and then excess returns of real estate securities will also be higher. As to the impact of financial freedom, being a measure of banking efficiency and a measure of independence from government control and interference in the financial sector, higher financial freedom will cause higher competitions and efficiencies for financial markets, which will decrease excess returns of financial commodities, such as real estate securities.

Fourth, comparing the results of model (4), (5), (6) and (7), after adding three indices of economic freedom, the absolute values of coefficients of MKT, SPREAD, OPENNESS, and FDI/GDP become bigger, hence, if three indicators of economic freedom is taken into the model of excess return of real estate securities, four variables, excess return of market, interest spread, openness, and FDI/GDP, will show higher effects. Conversely, the absolute value of coefficient of GDP becomes smaller, which means that the effect of economic growth on excess return of real estate securities becomes 
smaller.

Fifth, all of indicators are included into the model at the same time, as model (8), which shows a better estimating result because there are more significant coefficients of explanatory variables in model (8), comparing with the results of model (7). The empirical results of model (8) display that the coefficients of IF, MF, FF have same signs as the results of model (7). The coefficient of TF, an extra index of model (8), is significantly negative, which means that higher trade freedom will lower excess return of real estate securities. The index of trade freedom is a composite measure of the absence of tariff and non-tariff barriers, and higher index could increase international trade for a country, and the related increasing international economic integration could reduce the excess returns of real estate companies vis- ${ }^{\prime} \mathrm{a}-\mathrm{vis}$ the risk-free rate (Bardhan et al. [4]). Therefore, higher trade freedom could decrease the excess returns of real estate securities

\subsection{The GMM Estimations of Different Subsamples}

This section presents some further discussions about whether the effects of the different variables on excess return of real estate securities will be similar or different in three different regions or in two different income groups.

\subsubsection{The GMM Estimations of Three Areas}

Tables 4, 5, and 6 are the results of GMM estimation in Asian countries, -European countries, and other area's countries. Comparing the results of these tables, several features can display as the followings.

First, the coefficients of R (-1) are also positive and significant in all of models in Asia and other area, same as the result of all countries' sample. Conversely, the coefficients of R (-1) are negative and significant in most of models in Europe, that is to say, for the investors of real estate in Europe, if the excess return of real estate at the previous period is negative, which could cause the increasing demand of real estate and a positive excess return at the current period because the price of real estate is enough low to invest. On the contrary, if the excess return of real estate at the previous period is positive, which could bring about the decreasing demand of real estate and a negative excess return at the current period because the price of real estate is too high to buy.

Second, in terms the coefficients of company's factors, the coefficient of SIZE is significantly negative in most of the models for three different regions, which means that the firm's size is the important determinant for excess return of real estate. That is to say, investors may get abnormal profits by investing in smaller real estate companies, supporting the argument of a small effect (Fama and French [16]).

Third, on the aspect of the coefficients of macroeconomic variable, according to the Tables 4 and 5 , the coefficients of GDP growth, the proxy for local demand factor, are significantly positive of most of models in Europe and Asia, but most of them are insignificant in other area. This means that higher economic growth could stimulate the excess return of real estate firms in Europe and Asia, but there is no same effect in other area. The coefficients of SPREAD the proxy for local supply factor are insignificantly positive of most of models in three regions. Hence, the local demand factor "GDP" is the important determinant for excess return of real estate securities in all of three regions.

Fourth, the results of Table 6 are different from the results of the whole sample and other two regions. Most of the coefficients of company's factors, including SIZE, PTBV and LNTUR, are significant in other area, but the coefficients of macroeconomic variables are not, implying the more import factors for excess return of real estate securities are company's factors not macroeconomic variables in other regions. The countries of other area's sample include the countries in South Pacific, Africa, and America. Hence, the coefficients of macroeconomic variables are insignificant could be caused by the diversification of economic systems and policies in different regions' countries.

Fifth, in light of the coefficients of openness and FDI/GDP, for three regions, the signs of coefficients are the same as the results of the full sample. In Asia, Table 4 the coefficient of openness is significant, but globalization index "FDI/GDP" is insignificant for most of models. Amassing the possible reason, the economic development policy of many Asian countries is "export leads economic growth", which could cause that the variable "OPENNESS" became a key determinant of excess return of real estate property in Asia. The results of Europe and other area, Tables 5 and 6 are different from the results of Asia. In Europe and other area, the coefficients of both variables, OPENNESS and FDI/GDP, are significant for most of models in Table 5 and 6 . Finally, comparing the effects of four indexes of liberalization on excess return of real estate securities in three regions, models (7) and (8) in Tables 4, 5, and 6 , the indexes of financial freedom and Trade freedom are vital factors to change excess return of real estate securities in Asia, but all of four indexes of freedom can affect excess return of real estate securities in Europe and other area. 
Table 4. The results of GMM in Asia

\begin{tabular}{|c|c|c|c|c|c|c|c|c|}
\hline Variables/Model & 1 & 2 & 3 & 4 & 5 & 6 & 7 & 8 \\
\hline \multirow{2}{*}{$\mathrm{R}(-1)$} & $0.615^{*}$ & $0.186^{* * *}$ & $0.201 * * *$ & $0.417 * * *$ & $0.281 * * *$ & $0.356^{* * *}$ & $0.196^{* * *}$ & $0.211 * * *$ \\
\hline & $(0.077)$ & $(0.000)$ & $(0.001)$ & $(0.000)$ & $(0.000)$ & $(0.000)$ & $(0.004)$ & $(0.002)$ \\
\hline \multirow{2}{*}{ MKT } & $4.669 *$ & 1.173 & $15.634 * *$ & $34.573 *$ & $32.880 * *$ & 21.068 & 15.158 & 14.138 \\
\hline & $(0.098)$ & $(0.763)$ & $(0.034)$ & $(0.095)$ & $(0.021)$ & $(0.123)$ & $(0.285)$ & $(0.272)$ \\
\hline SIZE & & & $\begin{array}{l}-29.825 \\
(0.321)\end{array}$ & $\begin{array}{l}-49.354 \\
(0.171)\end{array}$ & $\begin{array}{c}-59.530 * * * \\
(0.004)\end{array}$ & $\begin{array}{c}-75.309 * * \\
(0.038) \\
\end{array}$ & $\begin{array}{c}-72.381 * * * \\
(0.005)\end{array}$ & $\begin{array}{c}-79.091 * * * \\
(0.003)\end{array}$ \\
\hline \multirow{2}{*}{ PTBV } & & & -0.014 & -0.083 & -0.045 & -0.009 & $-0.135^{* * *}$ & $-0.283 * * *$ \\
\hline & & & $(0.516)$ & $(0.494)$ & $(0.509)$ & $(0.928)$ & $(0.001)$ & $(0.002)$ \\
\hline \multirow{2}{*}{ LNTUR } & & & -13.256 & -0.867 & $-13.051 * *$ & -0.250 & $-18.577^{*}$ & $-18.861 *$ \\
\hline & & & $(0.145)$ & $(0.821)$ & $(0.019)$ & $(0.952)$ & $(0.092)$ & $(0.073)$ \\
\hline \multirow{2}{*}{ GDP } & & & $2.831^{* *}$ & $3.133^{*}$ & 0.406 & $7.232^{* *}$ & 1.545 & 0.857 \\
\hline & & & $(0.016)$ & $(0.060)$ & $(0.576)$ & $(0.045)$ & $(0.977)$ & $(0.958)$ \\
\hline \multirow{2}{*}{ SPREAD } & & & -18.101 & -22.523 & $-45.965 * * *$ & -2.058 & -38.062 & -27.664 \\
\hline & & & $(0.312)$ & $(0.222)$ & $(0.005)$ & $(0.913)$ & $(0.212)$ & $(0.382)$ \\
\hline OPENNESS & & $\begin{array}{l}-0.097 * \\
(0.062)\end{array}$ & & $\begin{array}{c}-2.305 * * * \\
(0.001) \\
\end{array}$ & & $\begin{array}{c}-1.952 * * * \\
(0.006)\end{array}$ & $\begin{array}{l}-1.803^{*} \\
(0.072)\end{array}$ & $\begin{array}{c}-1.787^{* * *} \\
(0.003)\end{array}$ \\
\hline I/GDP & & & & & $\begin{array}{c}1.273 \\
(0.643) \\
\end{array}$ & $\begin{array}{c}6.665 \\
(0.308) \\
\end{array}$ & $\begin{array}{l}10.111 \\
(0.143) \\
\end{array}$ & $\begin{array}{l}7.787^{*} \\
(0.061) \\
\end{array}$ \\
\hline IF & & & & & & & $\begin{array}{c}6.479 \\
(0.120) \\
\end{array}$ & $\begin{array}{c}6.149 \\
(0.211)\end{array}$ \\
\hline MF & & & & & & & $\begin{array}{l}-5.370 \\
(0.209) \\
\end{array}$ & $\begin{array}{l}-3.769 \\
(0.390)\end{array}$ \\
\hline $\mathrm{FF}$ & & & & & & & $\begin{array}{c}-10.822 * * \\
(0.023)\end{array}$ & $\begin{array}{l}-7.636^{*} \\
(0.064)\end{array}$ \\
\hline $\mathrm{TF}$ & & & & & & & & $\begin{array}{c}-10.018^{* * *} \\
(0.001)\end{array}$ \\
\hline P-Value & 0.730 & 0.583 & 0.674 & 0.525 & 0.341 & 0.956 & 0.896 & 0.894 \\
\hline
\end{tabular}

Note: P-Values are presented in parentheses. *Significance at the $10 \%$ level, **Significance at the $5 \%$ level, $* * *$ Significance at the $1 \%$ level. The Sargan test: The null hypothesis is defined as the instruments used that are not correlated with the residuals.

Table 5. The results of GMM in Europe

\begin{tabular}{|c|c|c|c|c|c|c|c|c|}
\hline Variables/Model & 1 & 2 & 3 & 4 & 5 & 6 & 7 & 8 \\
\hline \multirow{2}{*}{$\mathrm{R}(-1)$} & $-1.503^{*}$ & $-0.423 * *$ & $-0.327 * *$ & $-0.574 * * *$ & -0.214 & -0.341 & $-0.239 * * *$ & $-0.387 * * *$ \\
\hline & $(0.063)$ & $(0.180)$ & $(0.017)$ & $(0.001)$ & $(0.123)$ & $(0.014)$ & $(0.001)$ & $(0.004)$ \\
\hline \multirow{2}{*}{ MKT } & 12.187 & 5.410 & 18.632 & 18.195 & $8.162 *$ & $7.248^{* *}$ & 11.351 & $33.986^{* *}$ \\
\hline & $(0.140)$ & $(0.552)$ & $(0.207)$ & $(0.415)$ & $(0.081)$ & $(0.011)$ & $(0.331)$ & $(0.032)$ \\
\hline SIZE & & & $\begin{array}{c}-63.888^{*} \\
(0.074)\end{array}$ & $\begin{array}{c}-79.558 \\
(0.580)\end{array}$ & $\begin{array}{c}-56.125^{*} \\
(0.073)\end{array}$ & $\begin{array}{l}-31.122 \\
(0.214)\end{array}$ & $\begin{array}{l}-25.401 \\
(0.670)\end{array}$ & $\begin{array}{c}-16.430^{*} \\
(0.087)\end{array}$ \\
\hline \multirow{2}{*}{ PTBV } & & & $5.447^{*}$ & $7.569 *$ & 5.623 & 1.782 & $4.866^{* *}$ & 1.721 \\
\hline & & & $(0.085)$ & $(0.092)$ & $(0.251)$ & $(0.309)$ & $(0.049)$ & $(0.825)$ \\
\hline \multirow{2}{*}{ LNTUR } & & & -25.719 & -5.726 & 6.361 & 3.167 & 8.493 & 32.774 \\
\hline & & & $(0.274)$ & $(0.655)$ & $(0.629)$ & $(0.169)$ & $(0.476)$ & $(0.458)$ \\
\hline \multirow{2}{*}{ GDP } & & & $1.914 * *$ & $12.976^{* * *}$ & $4.112 *$ & $5.605^{* *}$ & 2.817 & $12.484 *$ \\
\hline & & & $(0.036)$ & $(0.009)$ & $(0.071)$ & $(0.041)$ & $(0.652)$ & $(0.069)$ \\
\hline \multirow{2}{*}{ SPREAD } & & & -3.514 & $-41.420 *$ & -5.318 & $-15.026^{* *}$ & -0.446 & -33.114 \\
\hline & & & $(0.698)$ & $(0.077)$ & $(0.317)$ & $(0.011)$ & $(0.981)$ & $(0.328)$ \\
\hline OPENNESS & & $\begin{array}{c}-2.873^{* *} \\
(0.028)\end{array}$ & & $\begin{array}{l}-11.831 \\
(0.117)\end{array}$ & & $\begin{array}{c}-3.625^{* *} \\
(0.013)\end{array}$ & $\begin{array}{l}-4.573^{*} \\
(0.093)\end{array}$ & $\begin{array}{c}1.742 \\
(0.328)\end{array}$ \\
\hline FDI/GDP & & & & & $\begin{array}{c}7.016^{* *} \\
(0.046)\end{array}$ & $\begin{array}{l}3.591^{*} \\
(0.065)\end{array}$ & $\begin{array}{c}3.287 \\
(0.811) \\
\end{array}$ & $\begin{array}{l}42.613 \\
(0.320) \\
\end{array}$ \\
\hline IF & & & & & & & $\begin{array}{l}7.778^{* *} \\
(0.047)\end{array}$ & $\begin{array}{l}1.710^{*} \\
(0.084)\end{array}$ \\
\hline MF & & & & & & & $\begin{array}{l}-3.061 \\
(0.745)\end{array}$ & $\begin{array}{c}-17.334 * * \\
(0.012)\end{array}$ \\
\hline $\mathrm{FF}$ & & & & & & & $\begin{array}{c}-4.464 * * \\
(0.022)\end{array}$ & $\begin{array}{l}-11.438 \\
(0.416)\end{array}$ \\
\hline $\mathrm{TF}$ & & & & & & & & $\begin{array}{c}-79.495^{* *} \\
(0.048)\end{array}$ \\
\hline P-Value & 0.672 & 0.806 & 0.998 & 0.994 & 0.877 & 0.581 & 0.997 & 0.994 \\
\hline
\end{tabular}

Note: P-Values are presented in parentheses. *Significance at the $10 \%$ level, **Significance at the $5 \%$ level, $* * *$ Significance at the $1 \%$ level. The Sargan test: The null hypothesis is defined as the instruments used that are not correlated with the residuals. 
Table 6. The results of GMM in other area

\begin{tabular}{|c|c|c|c|c|c|c|c|c|}
\hline Variables/Model & 1 & 2 & 3 & 4 & 5 & 6 & 7 & 8 \\
\hline \multirow{2}{*}{$\mathrm{R}(-1)$} & $0.215^{* *}$ & $0.294 *$ & $0.146 * * *$ & $0.304 * * *$ & $0.157 * * *$ & $0.324 * * *$ & $0.086^{*}$ & -0.071 \\
\hline & $(0.041)$ & $(0.064)$ & $(0.000)$ & $(0.000)$ & $(0.000)$ & $(0.000)$ & $(0.080)$ & $(0.544)$ \\
\hline \multirow{2}{*}{ MKT } & $14.236^{* *}$ & 2.733 & $9.953^{*}$ & 12.525 & $9.058^{*}$ & $20.635^{*}$ & 16.553 & $24.326^{* *}$ \\
\hline & $(0.010)$ & $(0.297)$ & $(0.097)$ & $(0.179)$ & $(0.069)$ & $(0.085)$ & $(0.426)$ & $(0.041)$ \\
\hline SIZE & & & $\begin{array}{l}-13.901 \\
(0.881) \\
\end{array}$ & $\begin{array}{r}-13.651 \\
(0.915) \\
\end{array}$ & $\begin{array}{c}-12.892^{* *} \\
(0.041)\end{array}$ & $\begin{array}{c}-19.043 * \\
(0.069) \\
\end{array}$ & $\begin{array}{l}-49.435 \\
(0.419) \\
\end{array}$ & $\begin{array}{c}-91.274 * \\
(0.079) \\
\end{array}$ \\
\hline \multirow{2}{*}{ PTBV } & & & $7.824 * * *$ & $7.167 * * *$ & $7.925 * * *$ & $7.094 * * *$ & $7.038 * * *$ & $4.651 * * *$ \\
\hline & & & $(0.000)$ & $(0.000)$ & $(0.000)$ & $(0.000)$ & $(0.000)$ & $(0.000)$ \\
\hline \multirow{2}{*}{ LNTUR } & & & -1.842 & -7.530 & -11.993 & $-7.684^{*}$ & $-8.531 * * *$ & -11.308 \\
\hline & & & $(0.856)$ & $(0.961)$ & $(0.891)$ & $(0.093)$ & $(0.003)$ & $(0.465)$ \\
\hline \multirow{2}{*}{ GDP } & & & $18.953 * * *$ & $22.617 * *$ & $18.897 * * *$ & $12.863 * *$ & 13.429 & $32.763 *$ \\
\hline & & & $(0.000)$ & $(0.024)$ & $(0.000)$ & $(0.012)$ & $(0.203)$ & $(0.057)$ \\
\hline \multirow{2}{*}{ SPREAD } & & & $-19.452 * * *$ & $-21.147^{*}$ & -13.182 & -12.236 & -0.810 & $-36.573 * *$ \\
\hline & & & $(0.000)$ & $(0.065)$ & $(0.618)$ & $(0.110)$ & $(0.959)$ & $(0.012)$ \\
\hline OPENNESS & & $\begin{array}{c}-1.722 * * * \\
(0.003)\end{array}$ & & $\begin{array}{l}-6.135^{*} \\
(0.072)\end{array}$ & & $\begin{array}{c}-8.123^{* *} \\
(0.031) \\
\end{array}$ & $\begin{array}{l}-6.544 \\
(0.216) \\
\end{array}$ & $\begin{array}{l}-6.517 \\
(0.159)\end{array}$ \\
\hline FDI/GDP & & & & & $\begin{array}{l}2.515^{* *} \\
(0.031)\end{array}$ & $\begin{array}{c}12.717 \\
(0.178) \\
\end{array}$ & $\begin{array}{l}15.646^{*} \\
(0.085) \text {. }\end{array}$ & $\begin{array}{c}7.153 \\
(0.637) \\
\end{array}$ \\
\hline IF & & & & & & & $\begin{array}{c}4.372 \\
(0.514)\end{array}$ & $\begin{array}{l}18.039^{*} \\
(0.056)\end{array}$ \\
\hline MF & & & & & & & $\begin{array}{c}-25.708 * * * \\
(0.000)\end{array}$ & $\begin{array}{l}-4.653 \\
(0.464) \\
\end{array}$ \\
\hline $\mathrm{FF}$ & & & & & & & $\begin{array}{c}-52.640 * * * \\
(0.004)\end{array}$ & $\begin{array}{c}-22.888^{*} \\
(0.090) \\
\end{array}$ \\
\hline $\mathrm{TF}$ & & & & & & & & $\begin{array}{c}-61.757^{*} \\
(0.059) \\
\end{array}$ \\
\hline P-Value & 0.546 & 0.824 & 0.728 & 0.668 & 0.732 & 0.651 & 0.317 & 0.139 \\
\hline
\end{tabular}

Note: P-Values are presented in parentheses. *Significance at the $10 \%$ level, $* *$ Significance at the $5 \%$ level, $* * *$ Significance at the $1 \%$ level. The Sargan test: The null hypothesis is defined as the instruments used that are not correlated with the residuals.

\subsubsection{The GMM Estimations of Different Income Groups}

Tables 7 and 8 are the results of high income countries and non-high income countries, respectively. Comparing the results of Tables 7 and 8 , several features can display as the followings.

First, the coefficients of $\mathrm{R}(-1)$ are positive and significant in all of models in non-high income groups, which is the same with the result of all countries' sample. As to the coefficients of R (-1) in high income countries, same as the results of Europe, they are negative and significant in most of models.

Second, in terms of the coefficients of company's factors, the variables SIZE and LNTUR are significant for most of the models in both of high and non-high income groups, which means that firm's size and turnover are important determinant for excess return of real estate securities in both groups. It's noteworthy that the sign of the variable LNTUR is positive in high income group; conversely, it is negative in non-high income group. In other words, increasing the turnover will raise excess return of real estate securities in high income countries, but there is a reverse effect in non-high income countries. The coefficients of GDP and Spread are insignificant for most of models in high income group. In non-high income group, the coefficient of Spread is also insignificant for most of models, but the coefficient of GDP is significant for most of models. In short, both of macroeconomics factors and company's factors can influence on the excess return of real estate securities in non-high income countries, but there is only company's factors affecting the excess return of real estate securities in high income countries.

Third, comparing the coefficients of openness and FDI/GDP in high and non-high income groups, in Tables 7 and 8 , the coefficient of OPENNESS is significantly positive for most of models in high income group, and it is significantly negative for most of models in non-high income group. Namely, higher degree of openness will increase excess returns of real estate securities in high income countries, but there is a converse effect in non-high income countries. The coefficients of FDI/GDP are insignificant for most of models in both groups. Hence, no matter in high or non-high income countries, the ratio of total trade to GDP is a key factor to affect excess return of real estate securities, but the ratio of FDI to GDP is less important.

Forth, in light of the effects of four indexes of liberalization on excess return of real estate securities in 
high and non-high income groups, models (7) and (8) in Tables 7 and 8, the coefficients of MF and TF are negative in both of income groups, which implies higher monetary freedom and Trade freedom will decrease excess return of real estate securities in both of income groups. The sign of the coefficients of IF is on contrary to each other in high and non-high income groups. The coefficient of IF is positive in high income group, but it is negative in non-high income group. Hence, increasing investment freedom will cause higher excess return of real estate securities in high income countries, but there is converse effect in non-high income countries. What caused the results? The countries in non-high income group are developing or undeveloped countries, and there are more controls and restrictions of capital outflow to invest foreign assets. If the governments of developing or undeveloped countries relax more restrictions of foreign investments, which cause capital outflows to invest foreign assets in developing or undeveloped countries. Hence, the excess return of real estate securities could be lower because of higher domestic capital outflows as investment freedom increases.

Finally, in Tables 7 and 8, the sign of the coefficient of FF is also on contrary to each other in high and non-high groups. Being different from the sing of IF, the coefficient of FF is negative in high income group, while it is positive in non-high income group. In developing or undeveloped, financial system is inefficient because of the existence of government control and interference in the financial sector. If the government of developing or undeveloped countries can relax more restrictions of financial system, the results of higher financial freedom could improve the efficiency of financial system, and it will improve the excess returns of real estate securities in non-high income countries.

Table 7. The results of GMM in high income group

\begin{tabular}{|c|c|c|c|c|c|c|c|c|}
\hline Variables/Model & 1 & 2 & 3 & 4 & 5 & 6 & 7 & 8 \\
\hline \multirow{2}{*}{$\mathrm{R}(-1)$} & $-0.378 * * *$ & $-0.390 * * *$ & $-3.05 * * *$ & $-0.390 * * *$ & $0.361 * * *$ & $-0.384 * * *$ & $-0.337 * * *$ & $-0.446 * * *$ \\
\hline & $(0.000)$ & $(0.000)$ & $(0.000)$ & $(0.001)$ & $(0.003)$ & $(0.000)$ & $(0.000)$ & $(0.000)$ \\
\hline \multirow{2}{*}{ MKT } & 60.798 & 67.701 & 10.721 & 83.933 & 61.460 & $59.200 * * *$ & $84.721^{* * *}$ & $60.429 * *$ \\
\hline & $(0.072)$ & $(0.411)$ & $(0.490)$ & $(0.103)$ & $(0.639)$ & $(0.002)$ & $(0.001)$ & $(0.040)$ \\
\hline SIZE & & & $\begin{array}{c}-88.345^{* *} \\
(0.036)\end{array}$ & $\begin{array}{l}-96.906 \\
(0.104)\end{array}$ & $\begin{array}{c}-25.064^{* * *} \\
(0.020) \\
\end{array}$ & $\begin{array}{l}-71.872 \\
(0.299)\end{array}$ & $\begin{array}{c}-110.821 \\
(0.201)\end{array}$ & $\begin{array}{c}-88.139^{* *} \\
(0.026)\end{array}$ \\
\hline \multirow{2}{*}{ PTBV } & & & -0.915 & $-1.406^{*}$ & -0.251 & -1.489 & -0.782 & -0.593 \\
\hline & & & $(0.314)$ & $(0.060)$ & $(0.813)$ & $(0.255)$ & $(0.551)$ & $(0.557)$ \\
\hline \multirow{2}{*}{ LNTUR } & & & $32.234 * * *$ & 33.650 & 26.058 & $42.983^{* * *}$ & $60.532 * * *$ & $41.813^{* * *}$ \\
\hline & & & $(0.000)$ & $(0.211)$ & $(0.253)$ & $(0.000)$ & $(0.002)$ & $(0.003)$ \\
\hline \multirow{2}{*}{ GDP } & & & 2.833 & 11.849 & $1.167 * * *$ & 1.546 & $27.359 * *$ & 13.374 \\
\hline & & & $(0.306)$ & $(0.289)$ & $(0.006)$ & $(0.673)$ & $(0.012)$ & $(0.337)$ \\
\hline \multirow{2}{*}{ SPREAD } & & & -26.452 & $-20.110 * *$ & -12.045 & $-39.024 *$ & -30.681 & -18.144 \\
\hline & & & $(0.127)$ & $(0.020)$ & $(0.176)$ & $(0.052)$ & $(0.229)$ & $(0.737)$ \\
\hline OPENNESS & & $\begin{array}{l}15.411^{*} \\
(0.097) \\
\end{array}$ & & $\begin{array}{l}7.095^{* *} \\
(0.021) \\
\end{array}$ & & $\begin{array}{c}10.859^{* *} \\
(0.029)\end{array}$ & $\begin{array}{c}2.321 \\
(0.620)\end{array}$ & $\begin{array}{c}6.108 \\
(0.169) \\
\end{array}$ \\
\hline FDI/GDP & & & & & $\begin{array}{c}1.009 \\
(0.978) \\
\end{array}$ & $\begin{array}{c}7.726 \\
(0.458) \\
\end{array}$ & $\begin{array}{l}3.512^{* *} \\
(0.021) \\
\end{array}$ & $\begin{array}{c}2.970 \\
(0.865) \\
\end{array}$ \\
\hline IF & & & & & & & $\begin{array}{l}11.799 \\
(0.201)\end{array}$ & $\begin{array}{c}14.779 * \\
(0.092)\end{array}$ \\
\hline MF & & & & & & & $\begin{array}{c}-43.183 * * * \\
(0.009)\end{array}$ & $\begin{array}{c}-44.237 * * \\
(0.011)\end{array}$ \\
\hline $\mathrm{FF}$ & & & & & & & $\begin{array}{l}-7.501 \\
(0.293)\end{array}$ & $\begin{array}{c}-10.202^{*} \\
(0.010)\end{array}$ \\
\hline $\mathrm{TF}$ & & & & & & & & $\begin{array}{l}-29.473 \\
(0.304) \\
\end{array}$ \\
\hline P-Value & 0.436 & 0.939 & 0.140 & 0.596 & 0.557 & 0.141 & 0.154 & 0.140 \\
\hline
\end{tabular}

Note: P-Values are presented in parentheses. *Significance at the $10 \%$ level, **Significance at the $5 \%$ level, ***Significance at the $1 \%$ level. The Sargan test: The null hypothesis is defined as the instruments used that are not correlated with the residuals. 
Table 8. The results of GMM in non-high income group

\begin{tabular}{|c|c|c|c|c|c|c|c|c|}
\hline Variables/Model & 1 & 2 & 3 & 4 & 5 & 6 & 7 & 8 \\
\hline \multirow{2}{*}{$\mathrm{R}(-1)$} & $0.118^{*}$ & $0.119^{*}$ & $0.015 * * *$ & $0.167 * * *$ & $0.013^{* * *}$ & 0.018 & 0.182 & $-0.181 * * *$ \\
\hline & $(0.091)$ & $(0.082)$ & $(0.000)$ & $(0.007)$ & $(0.000)$ & $(0.142)$ & $(0.125)$ & $(0.000)$ \\
\hline \multirow{2}{*}{ MKT } & $16.133 * *$ & $11.164^{* *}$ & $9.375^{* * *}$ & $3.027 * * *$ & $10.101^{* * *}$ & 8.016 & $12.724 * *$ & $14.983^{*}$ \\
\hline & $(0.031)$ & $(0.034)$ & $(0.001)$ & $(0.000)$ & $(0.002)$ & $(0.583)$ & $(0.039)$ & $(0.062)$ \\
\hline SIZE & & & $\begin{array}{c}-12.593 * * * \\
(0.000)\end{array}$ & $\begin{array}{l}-1.947 \\
(0.526)\end{array}$ & $\begin{array}{c}-12.189^{* * *} \\
(0.000)\end{array}$ & $\begin{array}{c}-15.687 * * * \\
(0.000)\end{array}$ & $\begin{array}{l}-12.315 \\
(0.110)\end{array}$ & $\begin{array}{l}-8.481 \\
(0.555)\end{array}$ \\
\hline \multirow{2}{*}{ PTBV } & & & 0.035 & $0.480 * * *$ & $0.057^{* *}$ & 0.181 & 1.096 & $1.163^{* * *}$ \\
\hline & & & $(0.199)$ & $(0.001)$ & $(0.049)$ & $(0.122)$ & $(0.158)$ & $(0.000)$ \\
\hline \multirow{2}{*}{ LNTUR } & & & $-4.946 * * *$ & $-1.831 * *$ & $-3.717 * * *$ & $-4.703 * *$ & $-2.245^{*}$ & $-3.794 * * *$ \\
\hline & & & $(0.000)$ & $(0.022)$ & $(0.000)$ & $(0.014)$ & $(0.091)$ & $(0.004)$ \\
\hline \multirow{2}{*}{ GDP } & & & $3.009 * * *$ & $0.557 * * *$ & $6.155^{* * *}$ & $8.605 * * *$ & $9.812 * *$ & 2.984 \\
\hline & & & $(0.000)$ & $(0.007)$ & $(0.000)$ & $(0.003)$ & $(0.021)$ & $(0.887)$ \\
\hline \multirow{2}{*}{ SPREAD } & & & -1.093 & $-1.462 *$ & $-5.306^{*}$ & -6.654 & -3.258 & -1.758 \\
\hline & & & $(0.662)$ & $(0.080)$ & $(0.093)$ & $(0.453)$ & $(0.121)$ & $(0.661)$ \\
\hline OPENNESS & & $\begin{array}{c}-0.916 \\
(0.121) \\
\end{array}$ & & $\begin{array}{c}-0.044 * * \\
(0.037)\end{array}$ & & $\begin{array}{c}-0.747^{* *} \\
(0.013)\end{array}$ & $\begin{array}{c}-0.179 * * \\
(0.049) \\
\end{array}$ & $\begin{array}{l}-0.184 \\
(0.851)\end{array}$ \\
\hline FDI/GDP & & & & & $\begin{array}{l}7.497 * * \\
(0.011)\end{array}$ & $\begin{array}{c}0.774 \\
(0.903)\end{array}$ & $\begin{array}{l}3.013^{*} \\
(0.069)\end{array}$ & $\begin{array}{l}15.352 \\
(0.367)\end{array}$ \\
\hline IF & & & & & & & $\begin{array}{c}-11.132 * * * \\
(0.001)\end{array}$ & $\begin{array}{c}-23.680^{* * *} \\
(0.006)\end{array}$ \\
\hline MF & & & & & & & $\begin{array}{l}-1.261 \\
(0.150) \\
\end{array}$ & $\begin{array}{c}-12.847^{* *} \\
(0.016)\end{array}$ \\
\hline $\mathrm{FF}$ & & & & & & & $\begin{array}{c}26.123 * * \\
(0.031) \\
\end{array}$ & $\begin{array}{l}42.046 \\
(0.244) \\
\end{array}$ \\
\hline $\mathrm{TF}$ & & & & & & & & $\begin{array}{c}-70.347^{* * *} \\
(0.008)\end{array}$ \\
\hline P-Value & 0.528 & 0.548 & 0.149 & 0.330 & 0.328 & 0.275 & 0.981 & 0.747 \\
\hline
\end{tabular}

Note: P-Values are presented in parentheses. *Significance at the $10 \%$ level, $* *$ Significance at the $5 \%$ level, $* * *$ Significance at the $1 \%$ level. The Sargan test: The null hypothesis is defined as the instruments used that are not correlated with the residuals.

\section{Conclusions}

This paper investigates the impact of trade and financial freedom on excess return of real estate securities for 1,108 firms in 24 countries, not only consider common risk and returns factor but also potentially related variables. To analyze the possible dynamism existing in multifactor model of return of real estate securities, the paper uses dynamic generalized method of moments. The important results of the paper are as the followings:

First, according to the empirical results of the whole sample, increasing international trade will reduce real estate firm excess returns while increasing Foreign Direct Investment (FDI) will increase real estate firm excess returns. Besides, the coefficients of the index of trade freedom and the index of financial freedom are significantly negative. Because higher trade freedom and financial freedom will increase international trade and financial integration across countries, which could increase efficiency of real estate market in a country and then will reduce the excess returns of real estate companies vis-'a-vis the risk-free rate. Next, increasing investment freedom will cause higher excess return of real estate securities, because investors can more freely and effectively allocate the portfolios of their investment. Finally, higher inflation will bring about lower monetary freedom, which will increase excess return of real estate securities because the price of real estate will caused by higher inflation.

Second, for the empirical results of three different regions, the variable OPENNESS is a main determinant of excess return of real estate in Asia, because the economic development policy for most of Asian countries is "export leads economic growth". The indexes of financial freedom and Trade freedom are vital factors to impact excess return of real estate securities in Asia, but excess return of real estate securities are affected by all of four indexes of freedom in Europe and other area.

Third, on the aspect of the empirical results of two income groups, the coefficient of OPENNESS is significantly positive for most of models in high income group, but there is inverse result in non-high income group. Higher monetary freedom and Trade freedom will cause excess return of real estate securities in both of income groups and increasing investment freedom will cause lower excess return of real estate securities in non-high income group, while there is converse effect in high income group. Being different from the sing of investment freedom, the 
coefficient of financial freedom is negative in high income group, while it is positive in non-high income group.

In general, the signs of the coefficients for most of variables in three different regions are similar the results of the full sample, but there are some regional differences of key variables to determine excess return of real estate securities. Besides, comparing the differences of two income groups, because most of the non-high income countries are developing or undeveloped, financial systems of these countries are unstable, which causes the coefficients of index of investment freedom and financial freedom are not consistent with the results of high income groups and whole samples.

\section{REFERENCES}

[1] Aizenman, J., \& Jinjarak, Y. Current account patterns and national real estate markets. Journal of Urban Economics, 66(2), 75-89, 2009.

[2] Arellano, M., \& Bond, S. Some tests of specification for panel data: Monte Carlo evidence and an application to employment equations. The review of economic studies, 58(2), 277-297, 1991.

[3] Ashok Bardhan and Cynthia A. Kroll. Globalization and the Real Estate Industry: Issues, Implications, Opportunities. Industry Studies Association Working Papers, 2007.

[4] Bardhan, A., Edelstein, R., \& Tsang, D. Global financial integration and real estate security returns. Real Estate Economics, 36(2), 285-311, 2008.

[5] Bardhan, A. D., Edelstein, R. H., \& Leung, C. A note on globalization and urban residential rents. Journal of Urban Economics, 56(3), 505-513, 2004.

[6] Bond, S. A., Karolyi, G. A., \& Sanders, A. B. International real estate returns: a multifactor, multicountry approach. Real Estate Economics, 31(3), 481-500, 2003.

[7] Berggren, N. The benefits of economic freedom: a survey. The independent review, 8(2), 193-211, 2003.

[8] Conover, M., Friday, S., \& Sirmans, S. Diversification benefits from foreign real estate investments. Journal of Real Estate Portfolio Management, 8(1), 17-25, 2002.

[9] Cotter, J., \& Stevenson, S. Multivariate modeling of daily REIT volatility. The Journal of Real Estate Finance and Economics, 32(3), 305-325, 2006.

[10] Cole, J. H. Contribution of Economic Freedom to World Economic Growth, 1980-99. Cato J., 23, 189, 2003.

[11] Eichholtz, P.M.A. The Stability of the Covariances of International Property Share Returns. Journal of Real Estate Research,11(2), 149-158, 1995.

[12] Eichholtz, P.M.A. and R. Huisman. The Cross Section of Global Property Share Returns. S.J.Brown and C.H.Liu, editors. A Global Perspective on Real Estate Cycles. Boston: Kluwer Academic Publishers, 1999.

[13] Eichholtz, P. M. Does international diversification work better for real estate than for stocks and bonds? Financial analyst's journal, 52(1), 56-62, 1996.

[14] Eichholtz, P., Huisman, R., Koedijk, K., \& Schuin, L. Continental factors in international real estate returns. Real Estate Economics, 26(3), 493-509, 1998.

[15] Fard, M. S., Cheong, K. C., \& Yap, S. F. Reopening the Debate on Globalisation and Economic Growth through Technology Transfer. Malaysian Journal of Economic Studies, 51(2), 231, 2014.

[16] Fama, E. F., \& French, K. R. The cross-section of expected stock returns. The Journal of Finance, 47(2), 427-465, 1992.

[17] Fama, E. F., \& French, K. R. Value versus growth: The international evidence. The journal of finance, 53(6), 1975-1999, 1998.

[18] Ferrero, A. House prices booms and current account deficits In 2011 Meeting Papers, number 1386. Society for Economic Dynamics, 2011.

[19] Ferrero, A. House price booms, current account deficits, and low interest rates. FRB of New York Staff Report, (541), 2012.

[20] Glascock, J. L., \& Kelly, L. J. The relative effect of property type and country factors in reduction of risk of international diversified real estate portfolios. Journal of Real Estate Finance and Economics, 34(3), 369-384, 2007.

[21] Glascock, J. L., Lu, C., \& So, R. W. M. Excess return and risk characteristics of Asian exchange listed real estate. Available at SSRN 907427, 2006.

[22] Goetzmann, W.N. and S.M. Wachter. The Global Real Estate Crash: Evidence from an International Database. Yale School of Management and the Wharton School. Unpublished working paper, 1996.

[23] Grubel, H. G. Economic freedom and human welfare: Some empirical findings. Cato J., 18, 287, 1998.

[24] Haan, J.D. \& Sturm, J. On the relationship between economic freedom and economic growth. European Journal of Political Economy, 16(2), 215-241, 2000.

[25] Heckelman, J.C. Economic freedom and economic growth: A short-run causal investigation. Journal of Applied Economics, 3(1), 71-91, 2000.

[26] Hamelink, F., \& Hoesli, M. What factors determine international real estate security returns? Real Estate Economics, 32(3), 437-462, 2004.

[27] Hoesli, M., Lekander, J., \& Witkiewicz, W. International evidence on real estate as a portfolio diversifier. Journal of Real Estate Research, 26(2), 161-206, 2004.

[28] Jinjarak, Y. and Sheffrin, S. Causality, real estate prices, and the current account. Journal of Macroeconomics, 33(2): 233-246, 2011.

[29] Kallberg, J. G., Liu, C. H., \& Pasquariello, P. Regime shifts in Asian equity and real estate markets, 2002.

[30] Ling, D. C., \& Naranjo, A. Commercial real estate return performance: a cross-country analysis. The Journal of Real Estate Finance and Economics, 24(1-2), 119-142, 2002.

[31] Ling, D. C., \& Naranjo, A. The integration of commercial 
real estate markets and stock markets. Real Estate Economics, 27(3), 483-515, 1999.

[32] Liow, K. H. Dynamic relationship between stock and property markets. Applied Financial Economics, 16(5), 371-376, 2006.

[33] Liow, K. H., \& Yang, H. Long-term co-memories and short-run adjustment: securitized real estate and stock markets. The Journal of Real Estate Finance and Economics, 31(3), 283-300, 2005.

[34] Liu, C. H., \& Mei, J. The predictability of international real estate markets, exchange rate risks and diversification consequences. Real Estate Economics, 26(1), 3-39, 1998.

[35] MacKinnon, G. H., \& Al Zaman, A. Real estate for the long term: The Effect of return predictability on long - horizon allocations. Real Estate Economics, 37(1), 117-153, 2009.

[36] Michayluk, D., Wilson, P. J., \& Zurbruegg, R. Asymmetric volatility, correlation and returns dynamics between the US and UK securitized real estate markets. Real Estate Economics, 34(1), 109-131, 2006.

[37] Ooi, J., \& Liow, K. H. Risk-adjusted performance of real estate stocks: Evidence from developing markets. Journal of Real Estate Research, 26(4), 371-396, 2004.

[38] Powell, B. Economic freedom and growth: The case of the Celtic tiger. Cato Journal, 22(3), 431-448, 2003.

[39] Serrano, C., \& Hoesli, M. Forecasting EREIT returns. Journal of Real Estate Portfolio Management, 13(4), 293-310, 2007.

[40] Wilson, P. J., \& Okunev, J. Evidence of segmentation in domestic and international property markets. Journal of Property Finance, 7(4), 78-97, 1996.

[41] Worzala, E., \& Sirmans, C. F. Investing in international real estate stocks: a review of the literature. Urban Studies, 40(5-6), 1115-1149, 2003. 